\title{
Analisis Efisiensi Pemasaran Produk Spa yang Laris Terjual pada PT Bali Tangi
}

\author{
NI KADEK WINDA YULIASARI, I GUSTI AGUNG AYU AMBARAWATI, \\ I KETUT RANTAU
}

\author{
Program Studi Agribisnis, Fakultas Pertanian, Universitas Udayana \\ Jl. PB. Sudirman Denpasar 80232 \\ Email: winda_yulia22@yahoo.com \\ annie_ambarawati@unud.ac.id
}

\begin{abstract}
Marketing Efficiency Analysis of Best Seller Spa Products at PT Bali Tangi

This research is aimed to find out the marketing channels, to calculate marketing margin, producer's share, and to analyze marketing efficiency of best seller spa products at PT Bali Tangi. This company produces three types of spa products namely scrub, masker and massage oil that are in high demand. Samples were selected purposively for retailers from PT Bali and snowball sampling for retailers from the wholesaler. Total samples were 30 from Denpasar City and Badung Regency including wholesaler, retailers, hotels and villas. The results showed that there are three types of marketing channels of best seller spa products of PT Bali Tangi. Channel I: producer - end consumers (for three spa products), channel II: producer - retailers and institutional consumers - end consumers (for three spa products), and channel III: producer - wholesaler - institutional consumers - end consumers (for only two spa products). The channel II comprises $52.95 \%$ of the total sales, whereas $8.97 \%$ and $38.07 \%$ respectively for channel I and III. The highest marketing margin was seen from the channel III at amount of Rp 80,000/unit, while no marketing margin coming from the channel $\mathrm{I}$ as it is direct marketing. The channel II has marketing margin Rp 25,000. The highest producer's share is on channel I by $100 \%$ and the lowest is on channel III by $57.89 \%$. The channel II has producer'share of $86.49 \%$. In terms of marketing efficiency, this research does not compare to channel I because channel I does not have a marketing agency. Channel II of the marketing channel is the most efficient based on three analysis of marketing margins, producer's share, and price efficiency. Channel III is only efficient at operational efficiency of 2,944.57\%. Meanwhile, channel III is inefficient. Despite of inefficiency, channel III is the main supporting channel for the company to maintain due to high volume of trading compared to channel I.
\end{abstract}

Keywords: spa products, marketing channels, marketing margins, producer's share, and marketing efficiency.

\section{Pendahuluan}

\subsection{Latar Belakang}

Kotler dan Keller (2012) menyatakan pemasaran merupakan mengidentifikasi dan memenuhi kebutuhan manusia dan sosial. Soekartawi (2002) menyatakan bahwa 
pemasaran merupakan aliran barang dari produsen ke konsumen. Aliran barang ini dapat terjadi karena adanya peranan lembaga pemasaran. Peranan lembaga pemasaran ini sangat tergantung dari sistem pasar yang berlaku dan karakteristik aliran barang yang dipasarkan, oleh karena itu dikenal istilah "saluran pemasaran" atau marketing channel.

Tjiptono (2015) menatakan bahwa saluran pemasaran adalah rute atau rangkaian perantara, baik yang dikelola pemasar maupun yang independen dalam menyampaikan barang dari produsen ke konsumen. Soekartawi (2002).menyatakan bahwa seringkali dijumpai adanya rantai pemasaran yang panjang dengan banyak pelaku pemasaran yang terlibat. Akibatnya, balas jasa yang diambil oleh para pelaku pemasaran menjadi besar yang mempengaruhi tingkat harga. Hal ini mengindikasikan sistem pemasaran yang terjadi belum efisien.

Kementerian Perindustrian (2014) menyatakan bahwa industri kosmetik nasional memberikan kontribusi yang cukup signifikan dari nilai ekspor, omzet, dan tenaga kerja. Dewi (2012) menyatakan bahwa Bali sebagai destinasi wisata tujuan utuma wisatawan domestik dan mancanegara terkenal memiliki keunggulan di bidang bisnis perawatan tubuh.

Asosiasi Produsen Produk Spa Denpasar (2015) menyatakan bahwa Bali telah berkembang menjadi wisata spa sehingga banyak bisnis di bidang produk spa di Bali. PT Bali Tangi merupakan salah satu perusahaan di Bali yang bergerak dalam penjualan produk spa. Produk yang paling tinggi penjualannya adalah scrub, masker, dan minyak pijat.

PT Bali Tangi menjalin kerjasama dengan berbagai lembaga pemasaran untuk mendistribusikan produk-produknya. Pada saat ini PT Bali Tangi hanya menjalin kerjasama dengan lembaga pemasaran di daerah Bali serta untuk memenuhi permintaan produknya di luar Bali maupun permintaan mancanegara PT Bali Tangi melakukan pemasaran dengan sistem online.

Tomek dan Robinson dalam Purwanto (2011) menyatakan bahwa keterlibatan lembaga pemasaran akan menyebabkan harga yang diterima produsen dan yang dibayarkan konsumen berbeda. Jumlah lembaga pemasaran yang dilalui akan berpengaruh terhadap bagian harga yang diterima produsen (producer's share) maupun yang harus dibayar konsumen. Semakin besar marjin pemasaran akan menyebabkan bagian harga yang diterima oleh produsen semakin rendah. Produk PT Bali Tangi dipasaran memiliki perbandingan harga ditingkat pengecer sangat jauh berbeda dengan harga ditingkat konsumen. Perbedaan harga tersebut mencapai tiga kali lipat lebih mahal ditingkat pengecer dengan harga ditingkat PT Bali Tangi. Harga produk minyak pijat $210 \mathrm{ml}$ pada PT Bali Tangi Rp 60.000, sedangkan di toko oleh-oleh khas Bali mencapai Rp 175.000.

Volume penjualan PT Bali Tangi juga belum mencapai target yang ditetapkan perusahaan, selain masalah harga produk spa PT Bali Tangi. Volume penjualan PT Bali Tangi disajikan pada Tabel 1. 
Tabel 1.

Volume Penjualan (Rp) Khusus Produk Spa PT Bali Tangi

\begin{tabular}{lcrr}
\hline \multirow{2}{*}{ Tahun } & $\begin{array}{c}\text { Volume } \\
\text { Penjualan(Rp) }\end{array}$ & \multicolumn{2}{c}{ Pertumbuhan } \\
\hline 2013 & 1.185 .082 .726 & & $\%$ \\
2014 & 1.565 .402 .185 & 380.319 .459 & 32 \\
2015 & 2.686 .050 .420 & 1.120 .648 .235 & 72 \\
\hline
\end{tabular}

Sumber: PT Bali Tangi, 2016

Tabel 1 menunjukkan bahwa volume penjualan produk spa PT Bali Tangi meningkat setiap tahunnya yaitu pada tahun 2014 meningkat sebesar 32\% dari tahun 2013 dengan total penerimaan yaitu Rp1.565.402.185 dan pada tahun 2015 meningkat sebesar $72 \%$ dari penjualan tahun 2014 yakni berjumlah Rp 2.686.050.420. Penjualan yang meningkat tentu berdampak positif bagi usaha PT Bali Tangi, namun penjualan setiap tahunnya belum mencapai target yang ditetapkan perusahaan yakni Rp 2,7 miliar per tahun. Belum tercapainya target penjualan tidak terlepas dari kompetitor produsen produk spa yang banyak di Bali sehingga PT Bali Tangi menghadapi persaingan.

Adanya perbedaan harga yang cukup tinggi di tingkat produsen (PT Bali Tangi) dan konsumen serta volume penjualan yang belum mencapai target, hal ini perlu dapat ditindaklanjuti dengan analisis efisiensi pemasaran.

\subsection{Rumusan Masalah}

Adapun rumusan masalah yang dapat diambil berdasarkan latar belakang di atas adalah sebagai berikut:

1) Saluran pemasaran apa saja yang digunakan oleh PT Bali Tangi untuk memasarkan produk spanya?

2) Bagaimana efisiensi pemasaran produk spa PT Bali Tangi yang laris terjual dilihat dari marjin pemasaran, producer's share, dan efisiensi pemasaran pada masing-masing saluran pemasaran?

\subsection{Tujuan Penelitian}

Berdasarkan dari latar belakang dan rumusan masalah di atas, maka penelitian ini bertujuan untuk mengetahui:

1) Saluran pemasaran yang digunakan oleh PT Bali Tangi dalam memasarkan produk spanya.

2) Efisiensi pemasaran produk spa PT Bali Tangi yang laris terjual dilihat dari marjin pemasaran, producer's share, dan efisiensi pemasaran pada masingmasing saluran pemasaran. 


\section{Metode Penelitian}

\subsection{Metode dan Waktu Penelitian}

Penelitian ini dilaksanakan di PT Bali Tangi J1. Kebo Iwa Utara No. 168 Denpasar. Pemilihan lokasi ini dilakukan dengan metode purposive dengan pertimbangan produk spa PT Bali Tangi dikenal masyarakat luas, PT Bali Tangi mendapat penghargaan produktivitas pramakarya tahun 2015, wakil Bali pada pameran Organic Europe tahun 2009, dan sebagian bahan baku PT Bali Tangi telah mendapat sertifikat organik dari Internal Control System (ICS). Pengambilan data dilaksanakan pada bulan Februari hingga bulan April 2017.

\subsection{Penentuan Populasi dan Sampel}

Populasi dalam penelitian ini adalah satu pedagang grosir dan 63 pengecer yang mempunyai kontak dengan PT Bali Tangi. Sugiyono (2016) menyatakan bahwa sampel adalah bagian dari jumlah dan karakteristik yang dimiliki oleh populasi. Cara menentukan sampel yang menggambarkan populasi, digunakan metode pengambilan sampel secara purposive dan snowball sampling. Pengambilan sampel untuk pengecer PT Bali Tangi digunakan purposive sampling. Sampel untuk pengecer pedagang grosir (UD Rajawali) digunakan snowball sampling. Sampel ditentukan secara purposive yaitu setengah dari jumlah populasi. Jumlah sampel yang diteliti sebanyak 30 yang terdiri atas 20 salon dan spa, tujuh hotel dan villa, dua swalayan, dan satu pedagang grosir.

\subsection{Teknik Pengumpulan Data, Variabel Penelitian, dan Metode Analisis}

Metode pengumpulan data yang digunakan dalam penelitian ini meliputi observasi dan wawancara para pihak yang terlibat dalam saluran pemasaran dengan menggunakan panduan wawancara. Variabel yang digunakan dalam penelitian ini adalah saluran pemasaran, marjin pemasaran, producer's share, efisiensi harga dan efisiensi operasional. Metode analisis yang digunakan adalah analisis deskriptif kualitatif dan kuantitatif. Analisis kualitatif membahas saluran pemasaran beserta fungsi-fungsi pemasaran yang dilaksanakan masing-masing lembaga pemasaran. Untuk analisis kuantitatif menggunakan rumus sebagai berikut:

1. Analisis Marjin Pemasaran

Secara matematis, rumus analisis marjin pemasaran (Kohls dan Uhl, 1998) adalah sebagai berikut :

$$
\mathrm{MP}=\mathrm{HBK}-\mathrm{HJP}
$$

Keterangan:

MP = Marjin pemasaran

HBK = Harga beli konsumen

HJP $=$ Harga jual produsen

\section{Analisis Producer's Share}


Kohls dan Uhl (1998) mendefinisikan producer's share sebagai persentase harga yang diterima oleh produsen dengan harga yang dibayarkan oleh konsumen dari kegiatan usahatani yang dilakukannya. Secara matematis producer's share dapat dirumuskan sebagai berikut :

$$
\mathrm{PS}=\frac{\mathrm{HJP}}{\mathrm{HBK}} \times 100 \%
$$

Keterangan:

PS = Bagian yang diterima produsen

HJP = Harga jual ditingkat produsen

HBK = Harga ditingkat konsumen

3. Analisis Efisiensi Pemasaran

Kohls dan Uhl (1998) menyatakan bahwa efisiensi pemasaran dapat dihitung dengan dua cara, yaitu:

a. Efisiensi harga (Pricing efficiency)

Efisiensi harga adalah perbandingan antara harga beli per unit yang dibayar konsumen dengan harga jual per unit yang diterima oleh produsen. Adapun rumus efisiensi harga adalah sebagai berikut :

$$
\mathrm{EH}=\frac{\mathrm{HBK}}{\mathrm{HJP}} \times 100 \%
$$

Keterangan:

$\mathrm{EH} \quad=$ Efisiensi Harga (\%)

HBK = Harga Beli Konsumen (Rp)

HJP = Harga Jual Produsen (Rp)

b. Efisiensi operasional (Operational efficiency)

Efisiensi operasisonal yaitu dengan membandingkan antara input pemasaran dengan outputnya. Adapun rumus untuk menghitung efisiensi operasional yakni:

$$
\mathrm{EO}=\frac{\mathrm{HBK}}{\text { Biaya Pemasaran (Rp/unit) }} \times 100 \%
$$

Keterangan :

EO

HBK

: Efisiensi Operasional (\%)

: Harga yang dibayar oleh konsumen untuk sebuah produk pada suatu saluran pemasaran (Rp/Unit).

Biaya pemasaran $(\mathrm{Rp} / \mathrm{Unit}) \quad$ : Biaya pemasaran yang terjadi pada suatu saluran distribusi (Rp/Unit).

\section{Hasil dan Pembahasan}

\subsection{Saluran Pemasaran PT Bali Tangi}

Berdasarkan hasil penelitian saluran pemasaran PT Bali Tangi melibatkan beberapa lembaga pemasaran yaitu satu pedagang grosir (UD Rajawali) dan pedagang pengecer yang terdiri dari: salon spa, hotel, villa, dan swalayan. Pada 
penelitian ini hanya difokuskan pada saluran pemasaran produk spa PT Bali Tangi di wilayah Kota Denpasar dan Kabupaten Badung. PT Bali Tangi menggunakan tiga tipe saluran dalam memasarkan produknya yaitu saluran I: produsen - konsumen akhir; saluran II: produsen - pengecer dan konsumen lembaga - konsumen akhir; dan saluran III: produsen - pedagang grosir - konsumen lembaga - konsumen akhir. Penjualan paling tinggi terdapat pada saluran II mencapai 52,95\% dari total penjualan, disusul oleh saluran III sebanyak 38,07\%, dan paling rendah pada saluran I hanya $8,97 \%$.

\subsection{Fungsi-fungsi Pemasaran}

Sudiyono (2004) menyatakan bahwa fungsi-fungsi pemasaran yang dilaksanakan oleh lembaga-lembaga pemasaran bermacam-macam, pada prinsipnya terdapat tiga tipe fungsi pemasaran yakni fungsi pertukaran, fungsi fisik, dan fungsi fasilitas. Berikut ini adalah pelaksanaan fungsi-fungsi pemasaran oleh masingmasing lembaga pemasaran.

1) PT Bali Tangi melaksanakan fungsi pertukaran, fungsi fisik, dan fungsi fasilitas.

2) Pengecer (salon spa, hotel villa, dan swalayan) melaksanakan fungsi pertukaran berupa fungsi pembelian dan penjualan serta fungsi fisik berupa fungsi penyimpanan.

3) Pedagang grosir melaksanakan fungsi pemasaran berupa fungsi pertukaran berupa fungsi pembelian dan penjualan serta fungsi fisik berupa fungsi pengangkutan dan penyimpanan.

\subsection{Analisis Marjin Pemasaran}

Analisis marjin pemasaran digunakan untuk melihat selisih harga yang dibayarkan konsumen akhir dengan harga ditingkat produsen. Hasil analisis marjin pemasarannya disajikan pada Tabel 2. Saluran pemasaran I tidak melibatkan perantara dan langsung diterima oleh konsumen akhir yang mengakibatkan marjin pemasaran pada saluran pertama Rp 0,00. Saluran I tidak dapat dibandingkan dengan saluran yang lain karena tidak terdapat perantara, sehingga saluran yang dapat dibandingkan adalah saluran II dan III karena, terdapat konsumen lembaga (KL) dan konsumen akhir (KA). KL adalah salon spa, hotel, dan villa yang menjual produk spa berupa jasa, sedangkan KA adalah konsumen akhir yang membeli produk spa bukan dalam bentuk jasa. KL tidak dapat dibandingkan karena produk yang dijual dalam bentuk jasa. Produk yang dibandingkan adalah scrub dan masker $1.000 \mathrm{~kg}$ pada KA, karena pada pedagang grosir hanya menjual produk scrub dan masker $1.000 \mathrm{~kg}$. Marjin pemasaran pada saluran II adalah Rp 25.000, sedangkan pada saluran III Rp 80.000. Saluran yang paling efisien adalah pada saluran II karena memiliki nilai marjin yang paling rendah. 
Tabel 2.

Marjin Pemasaran Produk Spa yang Terlaris Terjual

\begin{tabular}{|c|c|c|c|c|c|c|c|}
\hline \multicolumn{3}{|c|}{ Jenis Produk } & \multicolumn{5}{|c|}{ Marjin Pemasaran (Rp/Unit) } \\
\hline & \multirow{2}{*}{ gram } & \multirow{2}{*}{ mililiter } & \multirow{2}{*}{$\begin{array}{c}\text { Saluran I } \\
\text { KA }\end{array}$} & \multicolumn{2}{|c|}{ Saluran II } & \multicolumn{2}{|c|}{ Saluran III } \\
\hline & & & & KL & KA & KL & KA \\
\hline \multirow[t]{3}{*}{ Scrub } & 100 & - & 0 & - & 18.000 & - & - \\
\hline & 500 & - & 0 & - & 68.000 & - & - \\
\hline & 1.000 & - & 0 & 0 & 25.000 & 35.000 & 80.000 \\
\hline \multirow[t]{3}{*}{ Masker } & 100 & - & 0 & - & 18.000 & - & - \\
\hline & 500 & - & 0 & - & 68.000 & - & - \\
\hline & 1.000 & - & 0 & 0 & 25.000 & 35.000 & 80.000 \\
\hline Minyak & - & 35 & 0 & - & 20.000 & - & - \\
\hline \multirow[t]{3}{*}{ Pijat } & - & 210 & 0 & - & 60.000 & - & - \\
\hline & - & 500 & 0 & - & 40.000 & - & - \\
\hline & - & 1.000 & 0 & - & 25.000 & - & - \\
\hline
\end{tabular}

Keterangan:

KL : Konsumen Lembaga (Salon spa, Hotel, dan Villa)

KA : Konsumen Akhir

\subsection{Analisis Producer's Share}

Producer's share digunakan untuk melihat besarnya bagian yang diterima produsen dibandingkan dengan harga yang dibayarkan konsumen akhir. Producer's share memiliki hubungan negatif dengan margin pemasaran dimana semakin besar producer's share, maka bagian yang diperoleh produsen semakin besar.Hasil perhitungan producer's share disajikan pada Tabel 3. Tabel 3 menunjukkan bahwa saluran yang paling efisien antara produk scrub dan masker $1.000 \mathrm{~kg}$ konsumen akhir (KA) adalah saluran II karena memilik nilai producer's share yang tinggi yaitu $86,49 \%$. Saluran yang tidak efisien yaitu pada saluran ke III, karena nilai producer's share hanya $57,89 \%$. Perantara pada saluran III lebih banyak menaikan harga sehingga producer's share pada saluran III rendah, menyebabkan saluran III tidak efisien.

Tabel 3.

Producer's share Produk Spa PT Bali Tangi yang Laris Terjual

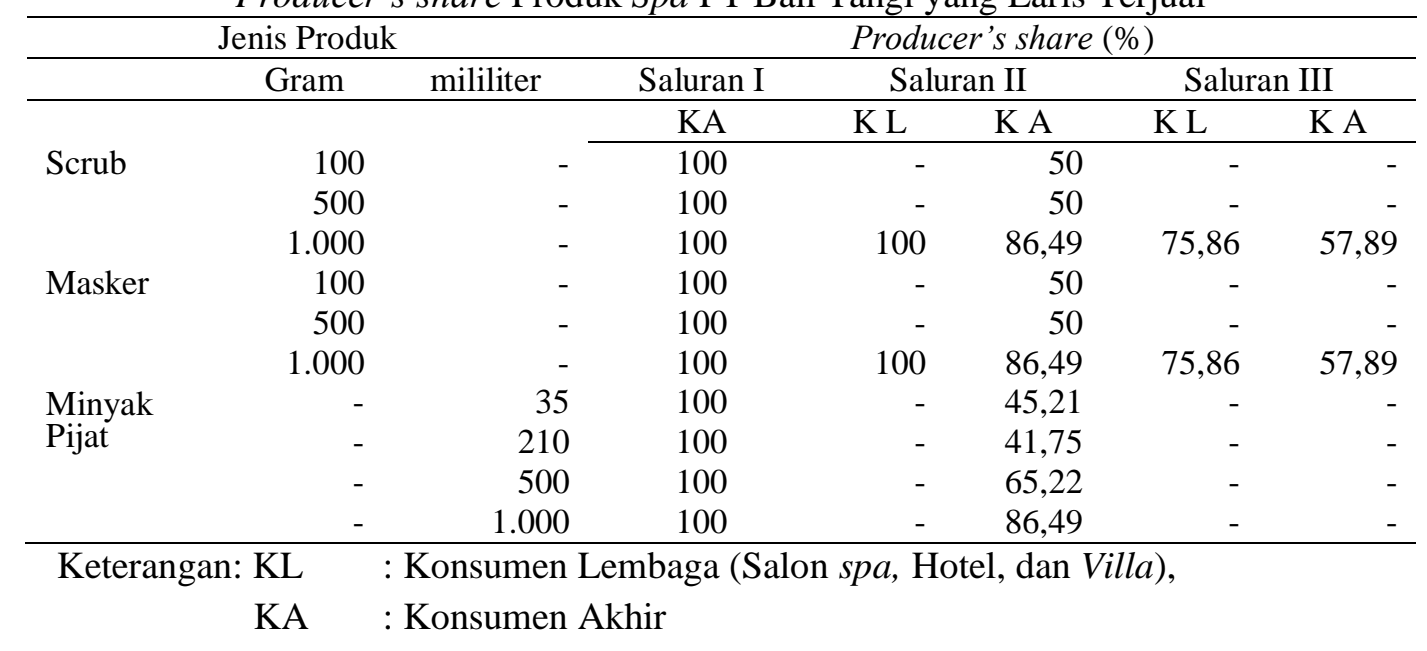




\subsection{Analisis Efisiensi Harga}

Efisiensi harga digunakan untuk menghitung perbandingan harga ditingkat konsumen akhir dengan ditingkat produsen. Semakin rendah nilai efisiensi harga, maka semakin efisien saluran tersebut. Hasil perhitungan disajikan pada Tabel 4.

Tabel 4.

Efisiensi Harga Produk Spa PT Bali Tangi yang Laris Terjual

\begin{tabular}{|c|c|c|c|c|c|c|c|}
\hline \multicolumn{3}{|c|}{ Jenis Produk } & \multicolumn{5}{|c|}{ Efisiensi Harga (\%) } \\
\hline & \multirow[t]{2}{*}{ gram } & \multirow[t]{2}{*}{ mililiter } & Saluran I & \multicolumn{2}{|c|}{ Saluran II } & \multicolumn{2}{|c|}{ Saluran III } \\
\hline & & & KA & KL & KA & KL & KA \\
\hline \multirow{3}{*}{ Scrub } & 100 & - & 100 & - & 200 & - & - \\
\hline & 500 & - & 100 & - & 200 & - & - \\
\hline & 1.000 & - & 100 & 100 & 115,63 & 131,82 & 172,73 \\
\hline \multirow[t]{3}{*}{ Masker } & 100 & - & 100 & - & 200 & - & - \\
\hline & 500 & - & 100 & - & 200 & - & - \\
\hline & 1.000 & - & 100 & 100 & 115,63 & 131,82 & 172,73 \\
\hline Minyak & - & 35 & 100 & - & 221,21 & - & - \\
\hline \multirow[t]{3}{*}{ Pijat } & - & 210 & 100 & - & 239,53 & - & - \\
\hline & - & 500 & 100 & - & 153,33 & - & - \\
\hline & - & 1.000 & 100 & - & 115,63 & - & - \\
\hline
\end{tabular}

Tabel 4 menunjukkan bahwa nilai efisiensi harga yang paling rendah antara produk scrub dan masker $1.000 \mathrm{~kg}$ konsumen akhir (KA) saluran II dan III adalah pada saluran II sebesar $115,63 \%$. Saluran yang tidak efisien adalah pada saluran III, karena nilai efisiensi harga tinggi mencapai $172,73 \%$. Besarnya nilai efisiensi harga pada saluran III disebabkan oleh pedagang grosir yang menaikan harga produk mencapai 1,73 kali lipat dari harga yang diberikan produsen.

\subsection{Analisis Efisiensi Operasional}

Efisiensi operasional disajikan pada Tabel 5. Tabel 5 menunjukkan bahwa nilai efisiensi operasional yang paling tinggi antara produk scrub dan masker $1.000 \mathrm{~kg}$ konsumen akhir (KA) saluran II dan III adalah pada saluran III sebesar 2.944,57\%. Nilai efisiensi operasional pada saluran III lebih tinggi dibandingkan pada saluran II karena harga pada konsumen akhir saluran III tinggi serta biaya pemasaran per unit yang dikeluarkan rendah. 
Tabel 5.

Efisiensi Operasional Produk Spa PT Bali Tangi yang Laris Terjual

\begin{tabular}{|c|c|c|c|c|c|c|c|}
\hline \multicolumn{3}{|c|}{ Jenis Produk } & \multicolumn{5}{|c|}{ Efisiensi Operasional (\%) } \\
\hline & \multirow[t]{2}{*}{ gram } & \multirow[t]{2}{*}{ mililiter } & \multirow{2}{*}{$\begin{array}{c}\text { Saluran I } \\
\text { KA }\end{array}$} & \multicolumn{2}{|c|}{ Saluran II } & \multicolumn{2}{|c|}{ Saluran III } \\
\hline & & & & KL & KA & KL & KA \\
\hline \multirow[t]{3}{*}{ Scrub } & 100 & - & $2.541,58$ & - & 546,75 & - & - \\
\hline & 500 & - & $1.948,55$ & - & 459,27 & - & - \\
\hline & 1.000 & - & $1.736,75$ & 190,54 & 404,59 & 50,55 & $2.944,57$ \\
\hline \multirow[t]{3}{*}{ Masker } & 100 & - & $2.541,58$ & - & 546,75 & - & - \\
\hline & 500 & - & $1.948,55$ & - & 459,27 & - & - \\
\hline & 1.000 & - & $1.736,75$ & 190,54 & 404,59 & 50,55 & $2.944,57$ \\
\hline Minyak & - & 35 & $7.261,67$ & - & $1.921,43$ & - & - \\
\hline \multirow[t]{3}{*}{ Pijat } & - & 210 & $2.622,27$ & - & 702,96 & - & - \\
\hline & - & 500 & $1.948,55$ & - & 503,01 & - & - \\
\hline & - & 1.000 & $1.736,75$ & 190,54 & 404,59 & - & - \\
\hline
\end{tabular}

Keterangan: KL : Konsumen Lembaga (Salon spa, Hotel, dan Villa)

KA : Konsumen Akhir

Secara keseluruhan dari ketiga alat analisis saluran II merupakan saluran yang paling efisien, sedangkan saluran III merupakan saluran yang efisien pada efisiensi operasionalnya saja. Kesimpulannya adalah saluran II merupakan saluran yang paling efisien dan saluran III merupakan saluran yang paling tidak efisien.

\section{Simpulan dan Saran}

\subsection{Simpulan}

1) PT Bali Tangi menggunakan tiga tipe saluran yaitu: saluran I produsen konsumen akhir; saluran II produsen - pengecer dan konsumen lembaga konsumen akhir; dan saluran III produsen - pedagang grosir - konsumen lembaga - konsumen akhir.

2) Ketiga alat analisis yaitu analisis marjin pemasaran, producer's share, dan efisiensi harga menunjukkan bahwa saluran II merupakan saluran yang paling efisien, sedangkan efisiensi operasional saluran III merupakan saluran yang efisien. Kesimpulannya saluran II merupakan saluran yang paling efisien dan saluran III merupakan saluran yang paling tidak efisien.

\subsection{Saran}

Saran yang dapat diberikan kepada PT Bali Tangi dalam memasarkan produk spa yaitu sebaiknya PT Bali Tangi lebih mempertahankan saluran II dengan tidak menghilangkan saluran pemasaran yang lain. Memperluas kerjasama dengan toko swalayan yang belum dimasuki PT Bali Tangi seperti pusat oleh-oleh khas Bali untuk meningkatkan volume penjualan. 


\section{Ucapan Terimakasih}

Penulis mengucapkan terimakasih kepada pihak yang telah mendukung terlaksananya penelitian ini yaitu kepada pihak PT Bali Tangi, responden penelitian yaitu: UD Rajawali, Nanami Oleh-oleh, Sanctuary Spa, 20 salon spa, empat hotel, dan tiga villa wilayah Kota Denpasar dan Kabupaten Badung yang tidak bisa disebutkan satu per satu, hingga karya ilmiah ini dapat dipublikasikan di e-jurnal.

\section{Daftar Pustaka}

Asosiasi Produsen Produk Spa Denpasar. 2015. Bali Denpasar Trading. http://spa.balidenpasartrading.com. Diakses 21 September 2016.

Dewi, Ida Ayu Mas Laksmi dan Eka Sulistyawati. 2016. Pengaruh Gaya Hidup dan Sikap Etnosentrisme Terhadap Niat Bali Konsumen Bali Alus. E-Jurnal Manajemen Universitas Udayana, 5(8):5128-5154.

Kementerian Perindustrian. 2014. Kemenperin Gelar Pameran Industri Kosmetik dan Jamu. Jakarta. http://www.kemenperin.go.id/artikel/10050/Kemenperin-GelarPameran- Industri-Kosmetik-dan-Jamu. Diunduh 20 Desember 2016.

Kohls, Richard L dan Joseph N, Uhl. 1998. Marketing of Agricultural Products. Eight Edition. London: The Macmillan Limited.

Kotler, Philip dan Kevin Lence Keller. 2012. Marketing Management $14^{\text {th }}$ edition. Jakarta: PT Indeks Klompok Gramedia.

Purwanto. 2011. Efisiensi Pemasaran Kayu Jenis Sengon. Universitas Islam Negeri Syarif Hidayatullah, Jakarta. repository.uinjkt.ac.id/dSpace/101198PURWANTO-FST.PDF. Diunduh 20 Oktober 2016.

Soekartawi. 2002. Prinsip Dasar Ekonomi Pertanian Teori dan Aplikasinya. Edisi Revisi 2002. Jakarta: PT Raja Grafindo Persada.

Sudiyono, Armand. 2004. Pemasaran Pertanian. Malang: Universitas Muhamadiyah Malang.

Sugiyono. 2016. Metode Penelitian Kuantitatif Kualitatif dan R\&D. Bandung: Alfabeta.

Tjiptono, Fandy. 2015. Strategi Pemasaran. Edisi Keempat. Yogyakarta: Andi. 